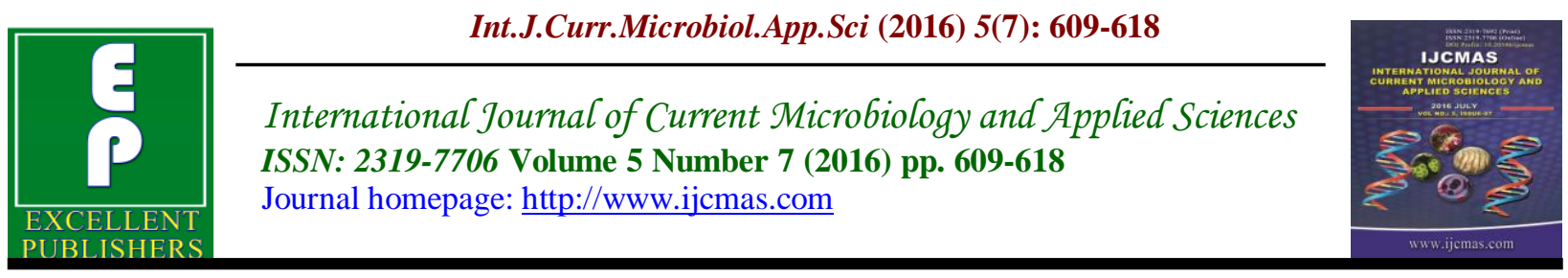

Original Research Article http://dx.doi.org/10.20546/ijcmas.2016.507.068

\title{
Evaluation of the Biocorrosion Inhibition Potential of Ethanol Extract of Ganoderma tropicum
}

\author{
Herbert O. Stanley ${ }^{1}$, Gideon O. Abu ${ }^{1}$ and Omega M. Immanuel ${ }^{2^{*}}$ \\ ${ }^{1}$ Department of Microbiology, University of Port Harcourt, Rivers State, Nigeria \\ ${ }^{2}$ World Bank African Centre of Excellence for Oilfield Chemicals Research, Institute of \\ Petroleum Studies, University of Port Harcourt, Rivers State, Nigeria \\ *Corresponding author
}

\begin{abstract}
A B S T R A C T
Keywords

Ganoderma

tropicum,

sulphate reducing

bacteria,

phytochemical, corrosion

inhibitor.

Article Info

Accepted:

20 June 2016

Available Online:

10 July 2016

This work investigated the inhibition effect of ethanol extract of Ganoderma tropicum on biocorrosion of carbon steel induced by a consortium of sulphate reducing bacteria (SRB). The SRB consortium used in this study included three Desulfovibrio sp. isolated from injection and produced water from Bonga oilfield in Nigeria. Isolation and gravimetric experiment were carried out in a Coy anaerobic chamber. Phytochemical screening of G. tropicum ethanol extract (GTEE) showed presence of alkaloid, glycosides, phenolic compounds, tannins, triterpenoids and steroids. Antimicrobial assay result revealed that GTEE was effective against SRB at $0.71 \mathrm{mg} / \mathrm{ml}$. GTEE+D-tyrosine treatment gave up to 5-log reduction in SRB population. The inhibition efficiency of the extract was $45.03 \% \mathrm{I}$ at sub-MIC, $59.12 \% \mathrm{I}$ at MIC, 63.81 at supra-MIC and 83.93 when potentiated with D-tyrosine for the 14-days test. The inhibition efficiency for the 28-days test was $43.19 \% \mathrm{I}$ at sub-MIC, 58.17\%I at MIC, 62.38 at supra-MIC and 72.09 when potentiated with D-tyrosine. The application of GREE in controlling SRB growth and activities can benefit the oil and gas industry as a green biocide and corrosion inhibitor.
\end{abstract}

\section{Introduction}

Microorganisms encounter metals of various kinds in their environment and can interact with them by binding them to their cell surface or by oxidizing them (Ehrlich, 2007). The opportunistic behaviour of microorganisms makes them able to meet their energy requirement while growing on metallic surfaces or in some instance where secreted metabolites such as organic acids are involved in the attack of metals, the energy released by the corrosion process is dissipated and not utilized by the cells $(\mathrm{Gu}$,
2012). One consequence of the ability of microorganism to oxidize metals is biocorrosion. Biocorrosion of metals and their alloys can occur whether they are submerged in water, buried in soil or exposed to the atmosphere; this is because the microorganisms that cause biodeterioration are widely distributed (Rajasekar et al., 2010).

Biocorosion is one of the consequences of biofouling of oil and gas installations such 
as pipelines, cooling circuits, production lines, injections lines and storage tanks. It brings irreversible deleterious changes in intrinsic properties of materials and can be particularly problematic in submerged pipelines and storage tanks, with great potential to cause environmental pollution. SRB are the most often reported culprits in biocorrosion. They cause biocorrosion of oil and gas facilities, notably the mesophilic $\mathrm{SRB}$ by the corrosive action of $\mathrm{H}_{2} \mathrm{~S}$ which they produce during sulphate respiration (Videla 2003; Wolicka and Borkowski, 2012; Cortás et al., 2012).

Physical and chemical measures are generally employed to keep industrial systems free from fouling agents, so as to prevent or control biocorrosion. Flushing (pigging) is perhaps the simplest physical approach, although of limited efficacy. A major biocorrosion prevention and control strategy for pipelines is by applying physical barriers between the environment and the pipes, in forms of coatings. Alumina and alumina nitride ceramics for use as structural materials in place of the expensive and yet fouling and biocorrosion susceptible steel structures have been proposed (Abu and Owate, 2003). With reference to chemical prevention and control of biocorrosion, the strategy is to introduce corrosion inhibitors and biocides into the oil and gas facility. Acetylenic alcohols and amines are commonly used corrosion inhibitor blends. Other compounds that have been used include nitrogen hetero-cyclic compounds, ammonia, morpholine, substituted thioureas and thiophenols.

The objective of using biocide in corrosion prevention and control is to prevent the growth and activities of microorganisms that influence corrosion. Most of the biocides available for biocorrosion control are ineffective against microbial biofims. This is mainly because some microorganisms in biofilms are shielded from the actions of biocides by the protective extracellular polymeric substances (EPS) coverings and extracellular enzymes present in the matrix (Suci et al., 1994; Anderson and O'Toole, 2008). New strategies in controlling biocorrosion are centered on keeping the microorganisms from forming biofilms, or by dispersing them from biofilms to render them more susceptible to the biocide. Ethylenediamine-N, N'-disuccinic acid (EDDS) and D-amino acids have been advocated for use as biofilm dispersal agents and biocide enhancers (Xu et al., 2013).

Mushroom extracts are excellent source of antimicrobial agents (Wasser and Weis, 1999). Bioactive substances namely ganomycins and ganoderic acid have been identified in Ganoderma sp. (Mothana et al., 2000; Chin et al., 2011; Chong et al., 2014). Results have also shown that some edible mushrooms are employed by traditional healers in the treatment of many infections (Etim et al., 2012). However, the use of mushroom extracts against SRB has not been reported in available literatures. The objective of this study was to investigate the efficacy of ethanol extract of Ganoderma tropicum as an antimicrobial and anticorrosion material.

\section{Materials and Methods}

\section{Plant collection and extraction}

Fruit bodies of $G$ tropicum were obtained from the Abuja campus of the University of Port Harcourt and identified at the Department of Plant Science Herbarium of the university, where voucher specimen was deposited. Extraction process was according to Okoro (2011) with modifications. Fruit bodies of $G$. tropicum were washed with distilled water and sun-dried for 7 days after 
which they were oven-dried for 15 minutes at $40^{\circ} \mathrm{C}$. One hundred grammes $(100 \mathrm{~g})$ of the dried fruit bodies were placed in $250 \mathrm{ml}$ Erlenmeyer flasks containing $150 \mathrm{ml}$ of $95 \%$ ethanol. The content was stirred gently using stirring rod, corked and kept in the laboratory for 72 hours. Filtration was done using Whatman filter paper No.1. The flasks with their contents were transferred into a water bath adjusted to $60^{\circ} \mathrm{C}$ to evaporate all the solvent and concentrate the extracts. Extracts were used to prepare the test solutions by dissolving appropriate masses of the extract from $(0.2 \mathrm{mg}-3.0 \mathrm{mg})$ in $1 \mathrm{ml}$ of distilled water.

\section{Preliminary phytochemical screening}

Procedure for phytochemical screening of extract for presence of alkaloids, flavonoids, phenolic compounds, tannins, glycosides, protein, triterpenoids and steroids was according to Shah et al. (2014).

\section{Fourier Transform Infra Red (FTIR) Spectroscopy}

Fourier Transform Infrared (FTIR) Spectroscopy (Perkin Elmer Spectrum BX11) analysis was carried out to confirm presence of functional groups representative of constituents. Extracts were mixed with $\mathrm{KBr}$ and made into a tablet before fixing to the FTIR sample plate. Absorption peaks were measured at 350 to 4000 wavenumbers $\mathrm{cm}^{-1}$. The absorption spectra bands gave interpretations of the chemical constituents of the extracts.

\section{Isolation of SRB}

Isolation of SRB was done using modified Postgate $\mathrm{B}$ medium containing in 1 litre: 1.0 $\mathrm{g}, \mathrm{CaSO}_{4}, 1.0 \mathrm{~g} \mathrm{NH}_{4} \mathrm{Cl}, 0.5 \mathrm{~g} \mathrm{KH}_{2} \mathrm{PO}_{4}, 2.0 \mathrm{~g}$ $\mathrm{MgSO}_{4} .7 \mathrm{H}_{2} \mathrm{O}, 1.0 \mathrm{~g} \mathrm{Na}_{2} \mathrm{SO}_{4}, 5.0 \mathrm{~mL}$ sodium lactate $60 \%, 1.0 \mathrm{~g}$ yeast extract, $0.1 \mathrm{~g}$ ascorbic acid, $0.1 \mathrm{~g}$ sodium thioglycolate, $0.5 \mathrm{~g} \mathrm{FeSO}_{4} .7 \mathrm{H}_{2} \mathrm{O}, 1.0 \mathrm{~g}$ sodium sulphate, 25 $\mathrm{g}$ sodium chloride and $15 \mathrm{~g}$ agar. The $\mathrm{pH}$ was adjusted by the addition of $5 \mathrm{M} \mathrm{NaOH}$ to make the final $\mathrm{pH}$ of the medium 7.0. The ferrous salt was sterilized separately and added to medium after cooling immediately before use. Nine millilitres $(9 \mathrm{ml})$ of culture broth was dispensed into sterile $10 \mathrm{ml}$ screw capped tubes. One millilitre (1) ml of sample was directly used as inoculum. Repeated sub-culturing in solid medium was carried out to obtain pure culture of isolates. All tubes were observed for blackening by SRB due to $\mathrm{H}_{2} \mathrm{~S}$ formation after 7 days of incubation at $30{ }^{\circ} \mathrm{C}$. Incubation was done in a Coy anaerobic chamber.

\section{Antimicrobial Assay of Extracts}

The procedure followed for antimicrobial assay was according to Korenblum et al. (2013) with modification. The minimum inhibitory concentration (MIC) and the minimum bactericidal concentration (MBC) of extract were determined to establish if the extract is bactericidal or bacteriostatic. Enhancement of antimicrobial activity of extract was carried out using D-tyrosine (Sigma-Aldrich).

\section{Gravimetric Experiment}

Carbon steel coupons $(0.1 \% \mathrm{C}, 0.4 \% \mathrm{Mn}$, $0.03 \% \mathrm{~S}, 0.06 \% \mathrm{P}$ and balance $\mathrm{Fe}$ ) of dimension $4.5 \mathrm{~cm} \times 1.0 \mathrm{~cm} \times 0.23 \mathrm{~cm}$, were smoothly polished using emery paper, cleaned briefly in $18 \% \mathrm{HCl}$, neutralized in sodium bicarbonate, washed with distilled water, rinsed in acetone, air dried and weighed using a digital weighing balance Citizen CY-204 with readabilty of $0.0001 \mathrm{~g}$. Metal coupons were conditioned using MIC of extracts for $24 \mathrm{~h}$ before placement into 10 ml screw cap tubes Korenblum et al. (2013). Two millilitres $(2 \mathrm{ml})$ of seed culture of 
SRB consortium was transferred into the tubes and filled to the brim with Postgate B growth medium under nitrogen purging. Blank control was untreated coupon in medium not inoculated with SRB cells. Cell control was untreated coupon in medium inoculated with SRB cells. At the end of the 14 and 28 days test period, metal coupons were cleansed briefly in acid, neutralized with sodium bicarbonate, rinsed in acetone, air dried and reweighed. Changes in weight were recorded. Experiments were performed in triplicate and the mean values of the weight loss were reported. Corrosion rate (CR) was calculated in milli-inch per year (mpy) using equation 1. The inhibition efficiency $(\% I)$ was be calculated as shown in equation 2.

$\mathrm{R}=\mathrm{KW} / \mathrm{DAT}$

Where $\mathrm{K}=$ rate constant 22,$300 ; \mathrm{W}=$ weight loss in grammes; $\mathrm{D}=$ density in $\mathrm{gcm}^{-}$ ${ }^{3}, \mathrm{~A}=$ exposed area in in. ${ }^{2}$ and $\mathrm{T}=$ time of exposure in days

$$
(\% I)=100\left[1-\left(\mathrm{W}_{2} / \mathrm{W}_{1}\right)\right]
$$

Where $\mathrm{W}_{1}$ is the corrosion rate in the absence of the inhibitor, $\mathrm{W}_{2}$ is the corrosion rate in the presence of the inhibitor.

\section{Results and Discussion}

\section{SRB isolates}

The isolates were identified as Desulfovibrio sp. on the basis of their cell morphology, motility, Gram reaction and presence of spores. The isolates were motile, vibroshaped, Gram-negative, non-spore forming mesosophiles. Desulfovibrio sp. is among the easily cultivatable mesophilic SRB isolated from oilfields (Youssef et al., 1999).

\section{Phytochemical screening}

Phytochemical analysis of $G$. tropicum ethanol extract (GTEE) indicated the presence of alkaloid, glycosides, triterpenoids, tannins and phenolics as constituents (Tables 1). The FTIR results indicated the presence $-\mathrm{OH}$ (alcohols and phenols); C-O (alcohols, esters and carboxylic acids); $\mathrm{C}=\mathrm{O}$ (esters, amines and carboxylic acids); $\mathrm{C}-\mathrm{H}$ (alkanes) and $\mathrm{C}=\mathrm{C}$ (alkenes and aromatic compounds) functional groups (Figure 1). Triterpenoids are reported as common secondary metabolites found in Ganoderma sp. with diverse range of biological activities (Zjawiony, 2004; Xia et al., 2014).

\section{Antimicrobial assay}

GTEE showed inhibitory effects against $\mathrm{SRB}$ at $0.71 \mathrm{mg} / \mathrm{ml} \mathrm{MIC}$. GTEE treatment alone gave up to 3-log reduction in SRB population (Table 2). The antimicrobial activities of a phenolic compound of $G$. tropicum against Staphylococcus aureus has been reported (Hu et al., 2013). To enhance the antimicrobial activity of the extract, Dtyrosine was added. Extract potentiated with D-tyrosine gave a 5-log reduction in SRB population. D-tyrosine has minimal antimicrobial potency. D-tyrosine is a nonessential amino acid with phenol functionality. It is a hydrophobic amino acid which can alter the activity of protein such as those found in the outer membrane of microorganisms. It is among the D-amino acids reported to have the ability to trigger the dispersal of established bacterial biofilms (Kolodkin-Gal et al., 2013). Dtyrosine has been reported to increase the antimicrobial activity of the widely used biocide THPS (Xu et al., 2012).

\section{Corrosion Rate and Corrosion Inhibition}


Corrosion rates and inhibition efficiencies results with and without GREE treatment are shown in Table 3 and 4 . The mean corrosion rate for untreated coupons without SRB cells for the 14 days test was 0.134 mpy, while that of untreated coupons with SRB cells was 0.362 mpy. The mean corrosion rate for untreated coupons without SRB cells for day 28 test was $0.175 \mathrm{mpy}$, while that of untreated coupons with SRB cells was 0.404 mpy. Corrosion rates at day 28 in the presence of extract were higher than at day 14 although the difference was not significant $(p<0.05)$. Results of the effect of temperature on corrosion rate are shown in Figure 2 and 3 . Corrosion inhibition efficiency increased with increase in concentration from sub-MIC to supra-MIC. Extract+D-tyrosine blend gave the highest inhibition efficiency of 83.93 (day 14) and 72.09 (day 28).

Table.1 Phytochemical screening of ethanol extract of Ganoderma tropicum

\begin{tabular}{llc}
\hline Phytochemical & Test & Observation \\
\hline Alkaloid & Mayer's test & - \\
& Wagner's test & - \\
& Dragendorff's & + \\
test & \\
Glycosides & Legal's test & + \\
& Keller-Killiani & + \\
test & \\
Proteins & Million's & - \\
Flavonoids & $\begin{array}{l}\text { Biuret } \\
\text { Shinoda test }\end{array}$ & - \\
Triterpenoids and Steroids & $\begin{array}{l}\text { Alkaline reagent } \\
\text { test }\end{array}$ & - \\
& $\begin{array}{l}\text { Libermann- } \\
\text { Burchard' test }\end{array}$ & + \\
Phenolics and Tannins & $\begin{array}{l}\text { Salkowski test } \\
\text { Ferric chloride } \\
\text { test }\end{array}$ & + \\
& Lead acetate test & + \\
\hline
\end{tabular}

Table.2 SRB population with and without treatment

\begin{tabular}{lccc}
\hline & \multicolumn{2}{c}{ MPN Values } \\
& \multicolumn{3}{c}{$\mathbf{9 5 \%}$ confidence limit } \\
\cline { 2 - 4 } Treatment & Value & Low & High \\
& & & \\
\hline Control & $8.7 \times 10^{7}$ & $4.47 \times 10^{7}$ & $1.71 \times 10^{8}$ \\
100 ppm D-tyrosine & $6.25 \times 10^{5}$ & $2.92 \times 10^{5}$ & $1.34 \times 10^{6}$ \\
0.71 (mgm/l) GTEE & $2.05 \times 10^{2}$ & $1.14 \times 10^{2}$ & $3.72 \times 10^{2}$ \\
$\mathbf{0 . 7 1}(\mathbf{m g} / \mathbf{m l})$ GTEE + & 7.5 & 3.6 & 15.9 \\
$\mathbf{5 0} \mathbf{~ p p m ~ D - t y r o s i n e ~}$ & & & \\
\hline
\end{tabular}


Table.3 Corrosion rates of carbon steel and inhibition efficiencies of GTEE (14-days test)

\begin{tabular}{lcc}
\hline Treatment & $\begin{array}{c}\text { Corrosion rate } \\
(\mathbf{m p y})\end{array}$ & $\begin{array}{c}\text { Inhibition efficiency } \\
(\% \boldsymbol{I})\end{array}$ \\
Blank control & 0.134 & - \\
Cell control & 0.362 & - \\
Sub-MIC & 0.199 & 45.03 \\
MIC & 0.148 & 59.12 \\
Supra-MIC & 0.131 & 63.81 \\
50 ppm D-tyrosine & 0.201 & 44.48 \\
MIC + 50 ppm D-tyrosine & 0.058 & 83.98 \\
\hline
\end{tabular}

Blank control $=$ untreated coupon $-\mathrm{SRB}$; cell control $=$ untreated coupon $+\mathrm{SRB}$

Table.4 Corrosion rates of carbon steel and inhibition efficiencies of GTEE (28-days test)

\begin{tabular}{lcc}
\hline Treatment & $\begin{array}{c}\text { Corrosion rate } \\
(\mathbf{m p y})\end{array}$ & $\begin{array}{c}\text { Inhibition efficiency } \\
(\boldsymbol{\%} \boldsymbol{I})\end{array}$ \\
Blank control & 0.175 & - \\
Cell control & 0.404 & - \\
Sub-MIC & 0.227 & 43.19 \\
MIC & 0.169 & 58.17 \\
Supra-MIC & 0.152 & 62.38 \\
50 ppm D-tyrosine & 0.219 & 45.79 \\
MIC + 50 ppm D-tyrosine & 0.113 & 72.09 \\
\hline \multicolumn{2}{c}{ Blank control = untreated coupon - SRB; cell control = untreated coupon + SRB }
\end{tabular}

Fig.1 FTIR spectrum for GTEE

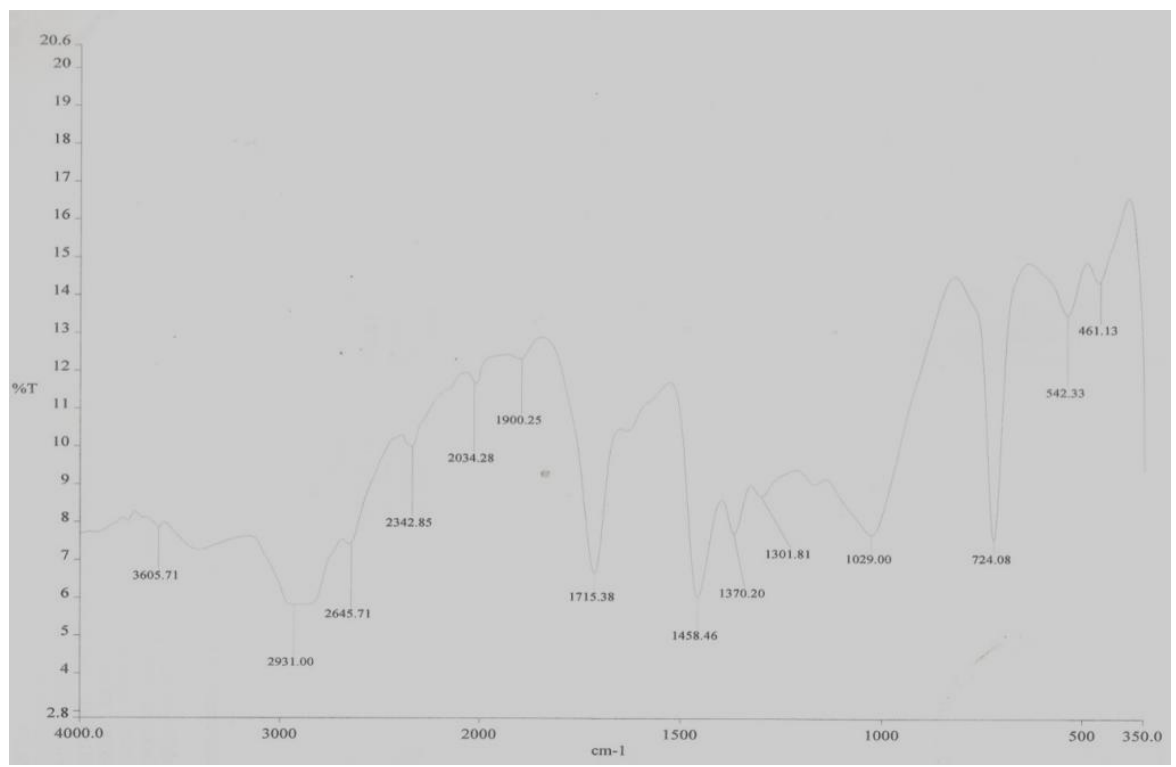


Fig.2 Corrosion rate with varying temperature in the presence and absence of GTEE (14-days test)

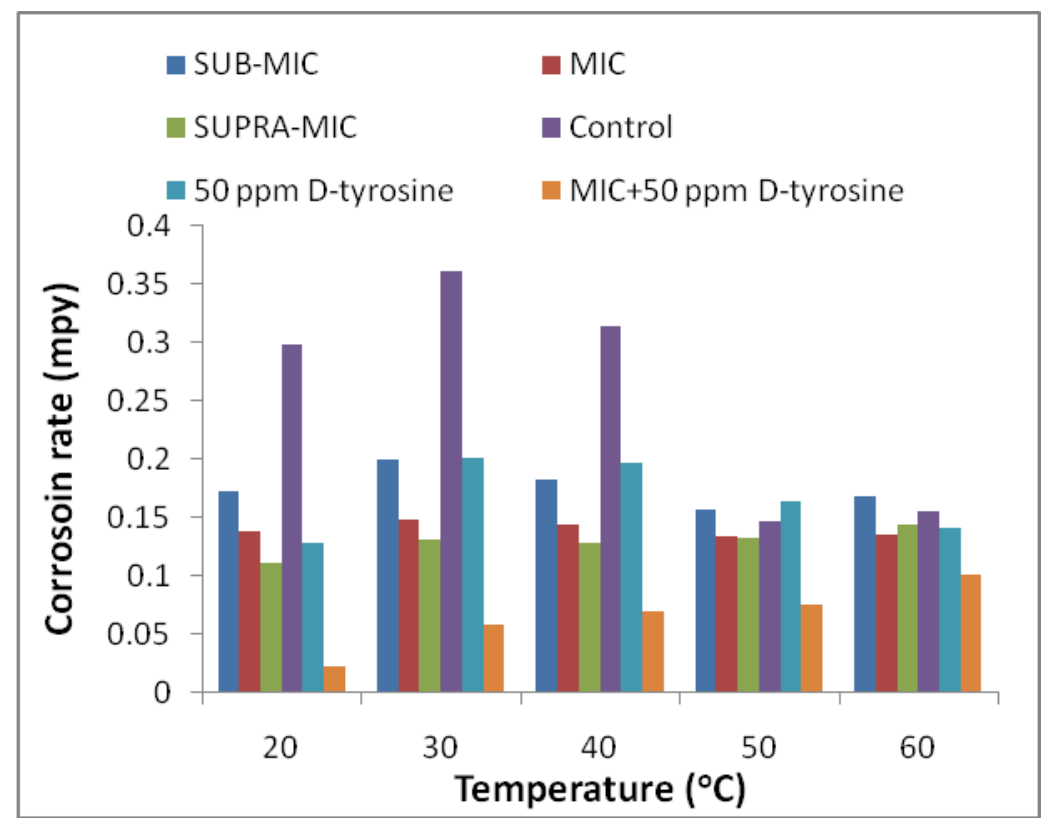

Fig.3 Corrosion rate with varying temperature in the presence and absence of GTEE (28-days test)

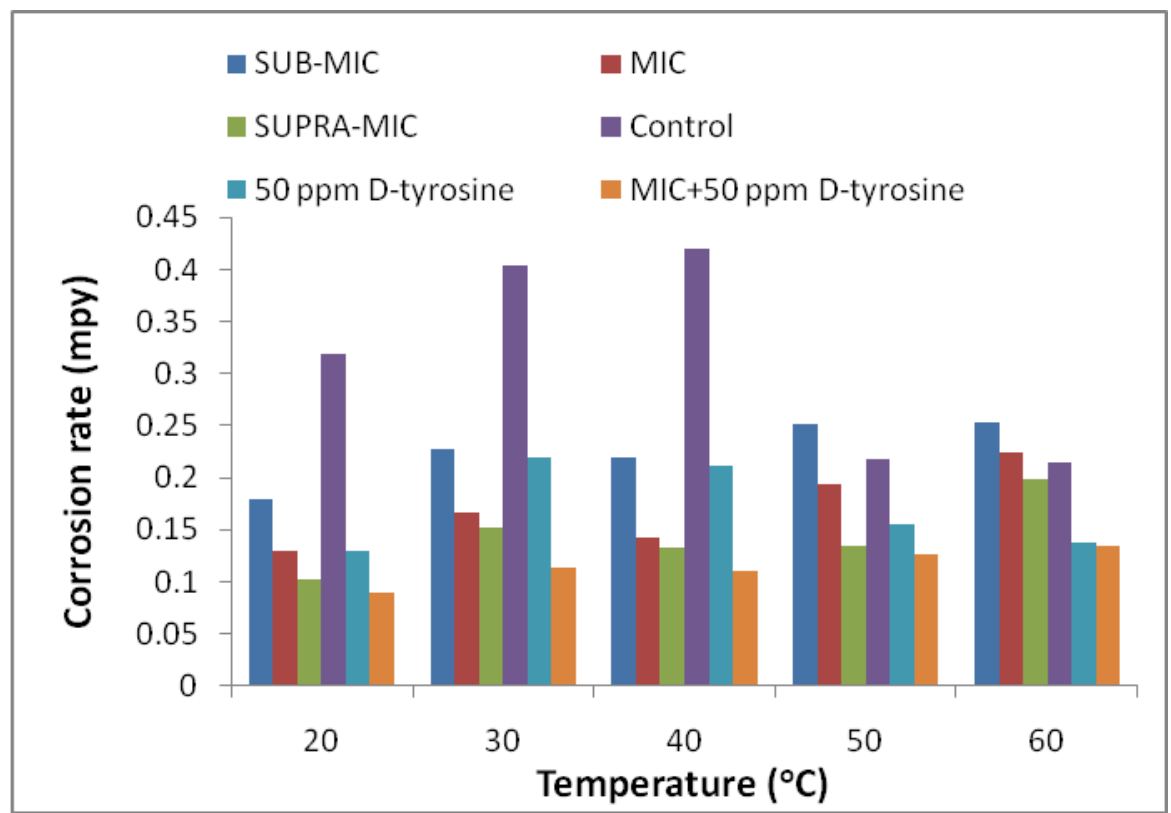

We attributed the corrosion inhibitory behavior of our extracts to their antimicrobial properties as well as to the adsorption of their molecules on the metal surface. Several studies have shown that plant extracts do bind to metal surfaces to form an unstable protective conditioning layer (Eddy and Ebenso, 2010; Nwaedozie et al., 2015). 
The inhibition efficiencies of the extracts were seen to reduce with exposure time and at higher temperatures. The efficiency of Eucalyptus camaldulenis extract was reported to decrease with exposure time while the corrosion rate increases with temperature (Abdulkhaleq, 2013). Dtyrosine has good inhibition efficiency against corrosion of carbon steel (Gowri et al., 2012). A synergistic effect was observed in our study as indicated by higher inhibition efficiency, when D-tyrosine combined with the extract.

Corrosion rates have been generally reported to increase with increase in temperature for chemical corrosion. Our investigation did not however show increase in corrosion rate with increase in temperatures with the exception of the extract + D-tyrosine blend. A likely reason for the observed difference is that temperature limits the activities of microorganisms. Temperatures above $40^{\circ} \mathrm{C}$ do not support growth and metabolism mesophilic of microorganisms such as our SRB isolates. Corrosion in the blank control where SRB cells were absent was attributed to chemical factors. Because extract potentiated with D-tyrosine gave insignificant cell counts, corrosion in the presence of extract + D-tyrosine was also attributed to chemical corrosion. Corrosion rates at temperatures above $40^{\circ} \mathrm{C}$ were close in value to the blank control. The microbial corrosion factor for day 14 test was determined to be 0.37 while that for day 28 was 0.43 . The minimum thickness ratio $\mu$ was $>0.75$. Hence the corrosion monitored was minor (Appuhamy et al., 2011).

In conclusion, not all biocides have antimicrobial and anticorrosion properties. Phytochemicals generally show good anticorrosion inhibition efficiency because they can bind to metal surfaces to form an unstable protective conditioning layer.
However their anticorrosion behavior in sour environment is generally poor. This is because souring most times is of biological origin, such that a mere coating of the surface of the metal by adsorption of extracts does not necessarily stop the corrosion process if the substance does not have a metabolic inhibition effect on the biological agents. Finding Phytochemicals with both antimicrobial and anticorrosion abilities like GTEE reported in this study is remarkable. It is note worthy that this extracts can be potentiated using an equally green chemical in the form of the amino acid D-tyrosine.

\section{Acknowledgment}

The authors wish to acknowledge World Bank African Centre of Excellence for Oilfield Chemicals Research for sponsoring this research.

\section{References}

Abdulkhaleq, L.G. 2013. The inhibitive effect of Eucalyptus camaldulenis leaves extracts on the corrosion of low carbon steel in $\mathrm{HCl}$. J. Engineering and develop., 17(3): 1555 - 1569.

Abu, G.O., Owate, I.O. 2003. Corrosion resistance of some ceramics in hostile environments. Scientia Africana, 2(1\&2): 99-105.

Anderson, G.G., O’Toole, G.A. 2008. Innate and induced resistance mechanisms of bacterial biofilms.Curr. Top. Microbiol. Immunol., 322: 85-105.

Appuhamy, J.M.R.S., Ohga, M., Kaita, T., Chun, P. and Dissanayake, P.B.R. 2011. Estimation of corrosioninduced strength deterioration of steel bridge plates- an analytical method. Annual Res J. SLSAJ., 11: 19-25.

Chin, S.K., Law, C.L. and Cheng, P.G. 2011. Effect of drying on crude ganoderic acids and water soluble 
content in Ganoderma lucidum. Int. J. Pharm. Pharm. Sci., 3(1): 3843-3854.

Chong, K., Ismail, K. and Abdullah, S. 2014. Screening for potential antimcrobial compounds from Ganoderma boninense against selected food borne and skin disease pathogens. Int. J. Pharm. Pharm. Sci., 6(2): 771-774.

Cortás, L.C., Carreira, M.V. and Costa, A.C.A. 2012. Biogenic production of sulfides in water-oil samples and its correlation with the deterioration of storage tank. Brazilian J. Petroleum and Gas, 6(3): 115-131.

Eddy, N.O. and Ebenso, E.E. 2010. Corrosion inhibition and adsorption properties of ethanol extract of Gongronema latifolium on mild steel in $\mathrm{H}_{2} \mathrm{SO}_{4}$. Pigment and Resin Technol., 39(2): 77 - 83.

Egan, M. 2011. Internal corrosion suspected as cause of Alaskan pipeline leak. Mater. Perform., 50(5): 14-23.

Ehrlich, H.L. 1997. Microbes and metals. Appl. Microbiol. Biotechnol., 48: 687692.

Etim, E.E., Akpan, I.U. and Edet, E.J. 2012. Antimicrobial properties of common mushrooms in Nigeria. Int. J. Modern Biol. Med., 2(2): 64-71.

Gowri, S., Sathiyabama, J., Prabhakar, P. and Rajendran, S. 2012. Inhibition behaviour of carbon steel in sea water in the presence of tyrosine- $\mathrm{Zn}^{2+}$ system. Int. J. Res. Chem. Environ., 3(1): 156-162.

$\mathrm{Gu}, \mathrm{T} .2012$. Can acid producing bacteria be responsible for very fast MIC pitting? NACE CORROSION/2012, paper no. 0001214. (Houston, TX: NACE, 2012).

Hu, L.L., Ma, Q.Y., Huang, S.Z., Guo, Z.K., Guo, J.C., Dai, H.F. and Zhao, Y.X. 2013. Two New Phenolic Compounds from the Fruiting Bodies of
Ganoderma tropicum. Bull. Korean Chem. Soc., 34(3): 884-886.

Kolodkin-Gal, L., Romero, D., Cao, S., Clardy, J., Kolter, R. and Losick, R. 2010. D-amino acids trigger biofilm disassembly. Sci., 328(5978): 627-639

Korenblum, E., Goulart, F. R. V., Rodrigues, I. A., Abreu, F., Lins, U. Alves, P. B., Blank, A. F., Valoni, E., Sebastián, G. V., Alviano, D. S., Alviano, C. S. and Seldin, L. 2013. Antimicrobial action and anticorrosion effect against sulphate reducing bacteria by lemongrass (Cymbopogon citratus) essential oil and its major component, the citral. AMB Express, 3: 44.doi: 10.1186/2191-0855-3-44.

Mothana, R.A., Jansen, R., Julich, W.D. and Lindequist, U.J. 2000. Ganomycins A and $\mathrm{B}$, new farnesyl hydorquinones from the basidiomycete Ganoderma pfeifferi. J. Nat. Prod., 63 (3): 416418.

Nwaedozie, J.M., Akpan, E. J. and Olufemi, A. 2015. Inhibition and adso-kinetics studies of Gmelina arborea fruit extract on corrosion of armoured steel plates in hydrochloric acid. Int. J. Scientific \& Engineering Res., 6(9): 701-717.

Okoko, F.J. 2011. Antimicrobial activity of aqueous and ethanol leaf extracts of Cassia alata on some clinical bacteria isolates. Int. Res. J. Microbiol., (IRJM), 2(11): 455-459.

Rajasekar, A., Anandkumar, B., Maruthamuthu, S., Ting, Y-P.and Rahman, P. K. S. M. 2010. Characterization of corrosive bacterial consortia isolated from petroleumproduct-transporting pipelines. Appl. Microbiol. Biotechnol., 85: 11751188.

Shah, P., Modi, H.A., Shukla, M.D. and Lahiri, S.M. 2014. Preliminary 
phytochemical analysis and antibacterial activity of Ganoderma lucidum collected from Dang District of Gujarat, India. Int. J. Curr. Microbiol. App. Sci., 3(3): 246-255.

Suci, P., Mittelman, M.W., Yu, F.P. and Geesey, G.G. 1994. Investigation of ciprofloxacin penetration into Pseudomonas aeruginosa biofilms. Antimicrob Agents Chemother., 38: 2125-2133.

Videla, H.A. 2003. Biocorrosion and biofouling of metals and alloys of industrial usage. Present state of the art at the beginning of the new millennium. Rei;. Metal. Madrid. Vol. Extr., 256-264.

Wasser, S.P. and Weis, A.L. 1999. Medicinal properties of substances occurring in higher basidiomycete mushrooms: current perspectives (review). Int. J. Med. Mushrooms, 1: 31-62.

Wolicka, D. and Borkowski, A. (2012).Microorganisms and crude oil, introduction to enhanced oil recovery (EOR) processes and bioremediation of oil-contaminated sites. Dr. Laura Romero-Zerón (Ed.), ISBN: 978-95351-0629-6, InTech, Available from: http://www.intechopen.com/books/intr oduction-toenhanced-oil-recovery-eorprocesses-and-bioremediation-of-oil- contaminated-sites/microorganismsandcrude-oil.

Xia, Q., Zhang, H., Sun, X., Zhao, H., Wu, L., Zhu, D., Yang, G., Shao, Y., Zhang, X., Mao, X., Zhang, L. and She, G. 2014. A comprehensive review of the structure elucidation and biological activity of triterpenoids from Ganoderma spp. Mol., 19: 17478-17535.

$\mathrm{Xu}$, D., Li, Y. and Gu, T. 2012. A synergistic D-tyrosine and tetrakis hydroxymethyl phosphonium sulfate biocide combination for the mitigation of an SRB biofilm. World J. Microbiol. Biotechnol., 28: 30673074.

Xu, D., Li, Y., Lindenberger, A.L., Liu, H., and $\mathrm{Gu}, \mathrm{T}$. 2013. "Green chemicals for enhanced biofilm mitigation", In: Microbial pathogens and strategies for combating them: science, technology and education. A. Méndez-Vilas (Ed.). Formatex. 90-101.

Youssef, N., Elshahed, M. and McInerney, M. 2009. Microbial processes in oil fields culprits, problems, and opportunities. Adv. Appl. Microbiol., 66: 141-251.

Zjawiony, J.K. 2004. Biologically active compounds from aphyllophorales (polypore) fungi. J. Nat. Prod., 67: 300-310.

\section{How to cite this article:}

Herbert O. Stanley, Gideon O. Abu and Omega M. Immanuel. 2016. Evaluation of the Biocorrosion Inhibition Potential of Ethanol Extract of Ganoderma tropicum. Int.J.Curr.Microbiol.App.Sci. 5(7): 609-618. doi: http://dx.doi.org/10.20546/ijcmas.2016.507.068 